\title{
Does Retaining Ligament Exist in the Neck?
}

\author{
Hyung-Jin Lee ${ }^{1}$, Seong-Yong Ryu ${ }^{2}$, Hyung-Jun $\mathrm{Ahn}^{2}$, Sung-Won Cho ${ }^{1}$, Hee-Jin Kim ${ }^{1}$, \\ Kyung-Seok $\mathrm{Hu}^{1}$ \\ ${ }^{1}$ Division in Anatomy and Developmental Biology, Department of Oral Biology, Human Identification Research Institute, \\ BK21 PLUS Project, Yonsei University College of Dentistry \\ ${ }^{2}$ Department of Oral Medicine, Temporomandibular Joint and Orofacial Pain Clinic, Yonsei University College of Dentistry \\ (Received 13 March 2017, revised 9 June 2017, accepted 14 June 2017)
}

\begin{abstract}
The goal of this study was to determine the characteristics of the horizontal cervical wrinkle and to investigate histological feature, especially with respect to elastin and collagen fiber.

Histologic sample were harvested from two fresh adult cadavers where the cervical wrinkle is in the neck. The tissue sections were stained with hematoxylin and eosin (HE) or Masson's Trichrome.

In sections of neck skin, keratinization was observed in the epidermis, and many collagen fibers were observed in the dermis layer as in other skin. Specifically, a lot of short and curly elastic fiber were observed between the collagen fibers in the dermis. These elastic fibers were not stained with eosin and observed in gray. This long ligament-like structures were observed in the dermis. The ligament-like structures were stained with dark red by trichrome. These results indicate that these ligament-like structures are neither typical ligament nor typical smooth muscles.

The results obtained from present study showed a ligamentous structure originating from the fascial layer (platysma muscle or investing layer). The results may help to understand the reasons about the formation of horizontal cervical wrinkle.
\end{abstract}

Keywords : Cervical horizontal wrinkle, Elastin fiber, Collagen fiber, Aging, Retaining ligament

\section{Introduction}

Aging is progressing and several wrinkles occur on the face. The underlying causes for these wrinkles are due to drooping or relocation and atrophy of the fat tissue, loss of skin and muscle tone, and deficiency of the elastin and collagen in the skin. Among them, the thick fibrous con-

\footnotetext{
*This article was supported by a faculty research grant of Yonsei University College of Dentistry (6-2016-0027).

The author(s) agree to abide by the good publication practice guideline for medical journals.

The author(s) declare that there are no conflicts of interest.

Correspondence to : Kyung-Seok Hu (Department of Oral Biology, Yonsei

University College of Dentistry)

E-mail : hks318@yuhs.ac
}

nective tissue holding toughly facial muscles on the face called as a retaining ligament, and it is regarded as a key structure to understand aging process [1].

Retaining ligaments are widely considered to have a strong dermal insertion of the face that pass the deep and superficial facial muscles [2-4]. The retaining ligaments have been described that consist of root in periosteal or deep fascial layer and radiate to dermis as tree-like pattern [4]. Also, these ligaments classified into two types, which are a true ligament proceeding from periosteum to dermis and second one is fasciocutaneous ligament combined with superficial and deep facial fasciae, especially in masseteric region [3]. Its characteristics are closely related with aging

(c) 2017 Korean Association of Physical Anthropologists

This is an Open Access article distributed under the terms of the Creative Commons Attribution Non-Commercial License (http://creativecommons.org/ licenses/by-nc/3.0) which permits unrestricted non-commercial use, distribution, and reproduction in any medium, provided the original work is properly cited.

ISSN 2287-626X (Online) · ISSN 1225-150X (Print) 
or making various facial wrinkles because the ligaments help and support the muscle and fat tissue attaching to the dermis against gravity $[1,3]$. According to the above-mentioned description, various facial wrinkle can be formed on the face such as tear trough, palpebromalar groove, labiomandibular fold and Jowl sagging [1].

The formation of several facial wrinkles can be made by the retaining ligament or the cutaneous insertion of the facial expression muscles including alar-facial crease and nasolabial crease [5-7]. However, the other region such as trunk, the skin fold could be made by the underlying fascial system including skin creases of the hand and inframammary crease [8,9]. Despite these varied studies, there is no report about histological feature and which structures form the horizontal cervical wrinkle in the neck region. Thus, the goal of this study was to determine the characteristics of the horizontal cervical wrinkle and to investigate histological feature, especially with respect to elastin and collagen fiber.

\section{Materials and Methods}

Histologic sample were harvested from two fresh adult cadavers; the wrinkle was found at the level of the laryngeal prominence, and most medial and lateral portion was harvested ( 1 male, 1 female; mean age, 72 y). The skin, subcutaneous fatty tissue, and platysma muscle were obtained from the neck of cadavers. The samples were fixed in $4 \%$ paraformaldehyde, dehydrated, embedded in paraffin, and sectioned at $6 \mu \mathrm{m}$ thickness. The tissue sections were stained with hematoxylin and eosin (HE) or Masson's Trichrome (HT15-1KT, Sigma-Aldrich, ST. Louis, MO, USA). The histologic analysis was performed and the photographs was taken by a microscope equipped with a CTR 6000 device (Leica Microsystem, Wetzlar, Germany).

\section{Results}

In sections of neck skin, keratinization was observed in the epidermis, and many collagen fibers were observed in the dermis layer as in other skin. Long ligament-like structures were observed in the dermis (Fig. 1). Based on its morphological aspects, it can be presumed to be either a collagen fiber bundle or a smooth muscle. To confirm

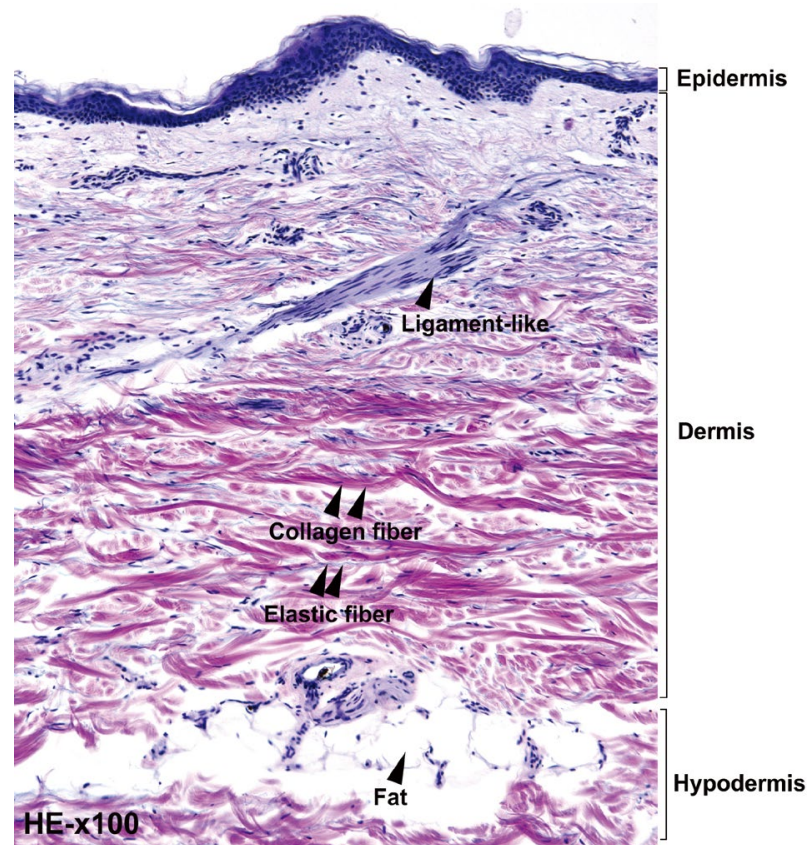

Fig. 1. HE histologic section obtained from the neck region where the horizontal cervical wrinkle is located. A ligamentous structure containing elastic fibers are visible between the muscle and dermis layer. This fiber originated from the muscle layer and radiated toward dermis layer.

whether these structures are ligament or smooth muscle, we performed Masson's trichrome staining further. Collagen fibers and muscles are stained blue and red, respectively by Masson trichrome. If it is a smooth muscle, it should be stained pink in HE stain and red in Masson's trichrome. In the other hand, it could be stained pink in HE stain and blue in Masson's trichrome if it is collagen fiber bundle.

As results, these ligament-like structures were observed in gray in HE stain. This ligament-like structures were stained with dark red by trichrome (Fig. 2A, B). These results indicate that these ligament-like structures are neither typical ligament nor typical smooth muscles. Specifically, a lot of short and curly elastic fiber were observed between the collagen fibers in the dermis. These elastic fibers were not stained with eosin and observed in gray. Additionally, elastic fibers are also stained red by trichrome. The color of this structure in the HE staining is similar to that of the wavy elastic fibers, so it can be assumed that the elastin component is abundant in this structure. Further studies on this field are highly required to identify the exact type and function of this structure. 

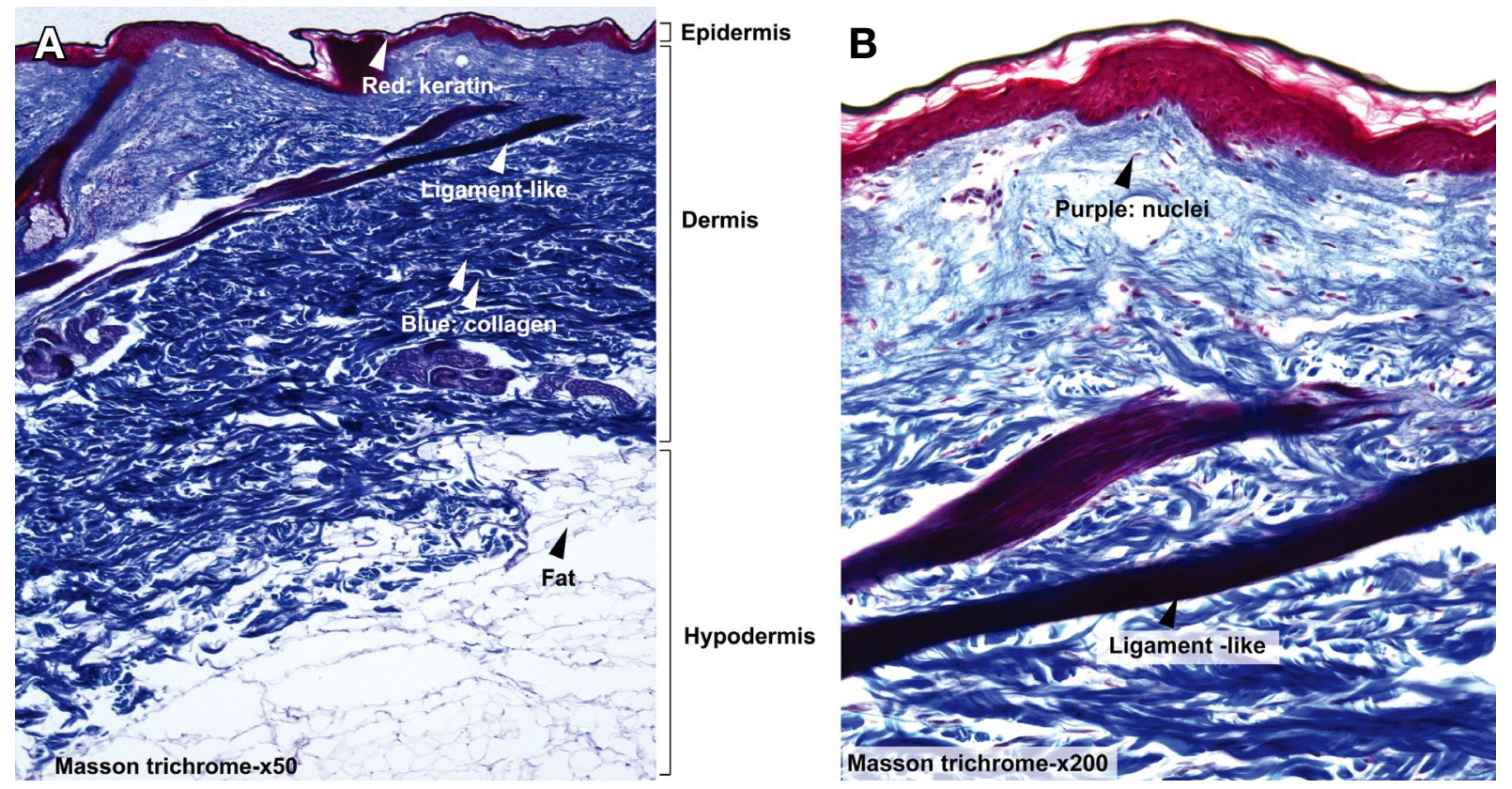

Fig. 2. Masson trichrome histologic section obtained from the neck region where the horizontal cervical wrinkle is located. A ligament-like structures were stained with dark red by trichrome (A and B).

\section{Discussion}

The goal of this study was to determine the characteristics of the horizontal cervical wrinkle and to investigate histological feature, especially with respect to elastin and collagen fiber. The present results imply the horizontal cervical wrinkle could be formed by a ligament-like structure supporting the dermis at the wrinkled area in the neck. However, we still have not figured out what exactly this ligament-like structure is by analyzing its morphology and colors in HE and Masson's trichrome stains. Based on the results, it may be assumed to be a variant of elastin-rich collagen fiber bundle or smooth muscle. Immunohistochemical staining using antibody for smooth muscle actin or Verhoeff's elastic staining is necessary for further study. What was clearly confirmed in this study was that curly elastic fibers were abundant throughout the dermis at the wrinkled area in the neck. The collagen and elastin in the dermis decrease as we age, therefore it is believed that the horizontal cervical wrinkle could be formed by this elastic fiber.

In the human body, there are various skin creases such as alar-facial, nasolabial fold in the face and inframammary, infragluteal, inguinal crease, and anterior axillary fold in the trunk. These structures are fixed and perpetual line on the body and have relation to connective tissue or muscle fibers attaching to the dermis that originate from the periosteum or superficial or deep fasciae [6]. Interestingly, the alar-facial crease exhibited rich elastin fiber [7] whereas the nasolabial crease is formed by the intermittent, cutaneous attachment of the surrounding mimic muscle such as zygomaticus major and minor, modiolus, and levator labii superioris muscle [5]. These muscles contain collagen and elastin, recently, Smith et al. [10] reported that the elastin content was found in $10 \%$ at the canine cruciate ligament. In the current study, near the horizontal cervical wrinkle, some ligamentous structures was observed. This ligamentous structures originated from the subcutaneous and attached to the dermis. Also, it radiated adjacent to dermis layer. This morphology is very similar that of retaining ligament of the face. The retaining ligament is an important anatomical structure to understand the aging and, especially during filler injection, to manage the several wrinkles that appear in the face. There are two types of retaining ligament in the face. The first originates from the periosteum and the second originates from the superficial and deep fascia to dermis. And these two retaining ligaments has a tree-like pattern attaching to the dermis [4]. The results obtained from present study showed a ligamentous structure originating from the fascial layer 
(platysma muscle or investing layer).

Unlike face, there is only a hyoid bone in the neck. The neck is also a structure that is mostly surrounded by muscles. Therefore, the retaining ligaments that originate from the periosteum appear to be extremely rare in the neck area. The observed ligamentous structure is believed to play an important role in maintain skin against gravity at the neck wrinkled area, although it was observed in small structure in the neck. Therefore, it is considered that a retaining ligament exists and forms wrinkles like the face in the area where the neck wrinkles are present.

To date, numerous anatomical and histological studies have been conducted on the face to determine the cause of wrinkles [2-5,7]. However, the explanation and research describing the cause of the horizontal cervical wrinkles are insignificant. The result obtained from this study may help to understand the reasons about the formation of horizontal cervical wrinkle.

\section{REFERENCES}

1. KIM HJ, Seo KK, Lee HK, Kim J. Clinical Anatomy of the Face for Filler and Botulinum Toxin Injection, General Anatomy of the Face and Neck pp 48-50: Springer Singa- pore, 2016.

2. Furnas DW. The retaining ligaments of the cheek. Plast Reconstr Surg. 1989; 83:11-6.

3. Stuzin JM, Baker TJ, Gordon HL. The relationship of the superficial and deep facial fascias: relevance to rhytidectomy and aging. Plast Reconstr Surg. 1992; 89:441-9; discussion 50-1.

4. Mendelson BC. Extended sub-SMAS dissection and cheek elevation. Clin Plast Surg. 1995; 22:325-39.

5. Barton Jr FE, Gyimesi IM. Anatomy of the nasolabial fold. Plast Reconstr Surg. 1997; 100:1276-80.

6. Mallouris A, Yiacoumettis A, Thomaidis V, Karayiannakis A, Simopoulos C, Kakagia D, et al. A record of skin creases and folds. Eur J Plast Surg. 2012; 35:847-54.

7. Patel JC, Fletcher JW, Singer D, Sullivan P, Weinzweig J. An anatomic and histologic analysis of the alar-facial crease and the lateral crus. Ann Plast Surg. 2004: 52:371-4.

8. Jones FW. The Principles of Anatomy as Seen in the Hand. London: Baillière. Tindall \& Cox. 1941.

9. Cooper, Sir Astley Paston, Bart. "On the anatomy of the breast-Of the internal parts of the breast, or mammary gland" (1840). On the anatomy of the breast, by Sir Astley Paston Cooper, 1840. Paper 9. http://jdc.jefferson.edu/ cooper/9

10. Smith KD, Clegg PD, Innes JF, Comerford EJ. Elastin content is high in the canine cruciate ligament and is associated with degeneration. Vet J. 2014; 199:169-74. 


\section{목에서 피부지지띠가 존재하는가?}

\section{이형진 ${ }^{1}$, 류성룡 $^{2}$, 안형준 ${ }^{2}$, 조성원 ${ }^{1}$, 김희진 $^{1}$, 허경석 $^{1}$}

${ }^{1}$ 연세대학교 치과대학 구강생물학교실, 해부 및 발생생물학연구실, 개인식별연구소, BK 21 PLUS Project

${ }^{2}$ 연세대학교 치과대학 구강내과학교실

간추림 : 본 연구의 목적은 조직염색을 통해 목가로주름의 특징을 살펴보고 특히 탄력 및 아교섬유의 조직학적 특성 을 살펴보는 것이다.

한국인 성인 신선 시신 2 구에서 목가로주름이 위치한 방패연골의 후두융기 높이에서 가장 가쪽과 안쪽의 조 직표본을 채취하였다. 채취한 표본은 Hematoxylin and eosin(HE) 및 Masson’s Trichrome으로 염색하였다.

염색된 표본에서는 표피에 각질화가 관찰되었고 다른 피부와 마찬가지로 진피층에 많은 아교섬유가 관찰 되었다. 특히 진피의 아교섬유 사이에는 짧고 구불구불한 형태의 탄력섬유가 많이 관찰되었다. 이 탄력섬유는 에오신으로 염색되지 않았으며 회색으로 관찰되었다. 이 긴 인대로 추정되는 구조는 진피에서 관찰되었으며, Masson's Trichrome 염색 시 진한 붉은 색으로 염색되었다. 이러한 결과는 인대로 추정되는 구조가 전형적인 인 대도 일반적인 민무늬근도 아님을 시사한다.

본 연구에서는 목근막얕은층에서 기원하는 인대와 비슷한 구조를 조직염색을 통해 관찰하였으며, 이를 통해 목가로주름 형성에 대한 기전을 이해하는 데 도움이 될 수 있을 것으로 생각한다.

찾아보기 낱말 : 목가로주름, 탄력섬유, 아교섬유, 노화, 피부지지띠 